\title{
DISCUSSION
}

\section{Sulphate analysis on black mudstones}

\author{
A. B. HAWKINS and G. M. PINCHES (1987), Géotechnique 37, No. 2, 191-196
}

\section{Dr P. J. Loveland, Soil Survey of England and Wales}

The Authors are to be congratulated for pointing out the dangers of the unexpected oxidation of pyrite (iron sulphide) in soil materials. However, $\mathrm{SO}_{3}$ is sulphite not sulphate, which is $\mathrm{SO}_{4}$.

During a survey of England and Wales, the Soil Survey was faced with the problem of screening several thousand soil samples for potential acidity caused by the formation of sulphuric acid from the oxidation of pyrite. $\mathrm{pH}$ change was utilized before and after slow, moist oxidation. The technique was very simple, and the procedure is as follows.

(a) Place the field sample (a few grammes) in a polythene bag and roll it tightly to squeeze out any air. If there is to be much delay before reaching the laboratory, place the sample in a cool-box.

(b) Measure the $\mathrm{pH}$ of the sample as soon as possible.

(c) Expose the rest of the sample to the air for three months simply by rolling the edges of the bag back.

(d) Keep the sample moist using distilled or deionized water (don't use tap water--if hard, it may neutralize any acidity produced). During this exposure period, stir the sample occasionally.

A fall in $\mathrm{pH}$ of more than 0.5 units was significant.

One person can service several hundred samples in this manner on a rolling basis, and only a relatively small amount of space is required. The measurement of $\mathrm{pH}$ is much quicker, simpler and cheaper than that of sulphate. The latter may prove to be required on only a few samples. The lowest $\mathrm{pH}$ recorded during the survey was 1.4 . Unfortunately, there is no quantitative relationship between the initial amount of sulphite or the amount of sulphate formed, and change in $\mathrm{pH}$.

In practice, many samples with appreciable amounts of pyrite showed a marked change in pH after one or two weeks. If a rapid result is required, the pyrite can be oxidized by the addition of a few drops of hydrogen peroxide solu- tion. The reaction can, however, be extremely violent, so great care should be taken.

This Writer questions the authors' recommendation (p. 195) to 'provide adequate drainage to remove newly formed sulphates and to prevent onset of acidic conditions'. Drainage will aerate the soil and produce just those conditions which will promote oxidation of pyrite and hence formation of sulphate. Sulphates are unlikely to be removed completely from drainage waters in a reasonable time. Current thinking in agricultural practice in areas of potentially acid sulphate soil is to keep it undrained and hence keep the air out (Bloomfield \& Coulter, 1973). However, this may not always be practicable in a civil engineering context.

Finally, it is sometimes suggested that calcium carbonate be applied to neutralize any acidity. This is usually impracticable; a layer of soil $30 \mathrm{~cm}$ thick and 1 ha in extent containing $1 \%$ by weight of oxidizable sulphur (by no means an uncommon value) would require at least 100 tonnes of $\mathrm{CaCO}_{3}$ to neutralize all the potential acidityassuming such a quantity could be adequately incorporated into the soil matrix.

\section{Author's reply}

The Authors accept that to be chemically accurate sulphate should be referred to as $\mathrm{SO}_{4}{ }^{2-}$. However, to be consistent with the engineering literature the authors continue to quote sulphate as $\mathrm{SO}_{3}$, following BS 1377 (1975) Methods of test for soils for civil engineering purposes. In the authors' opinion, to have moved away from the terminology used in this Standard would have caused considerable confusion.

Dr Loveland's comments concerning the overall application of potential acidity using $\mathrm{pH}$ as a general indicator are appreciated. His procedure is a good, economical means of monitoring changes in soil acidity. However, we would point out that a change in $\mathrm{pH}$ does not necessarily imply a change in the sulphate content, as $\mathrm{pH}$ may also be lowered by other acids. It should be emphasized that, as Dr Loveland states, there is no quantitative relationship between the amount of sulphate formed and the variation in $\mathrm{pH}$. It would be misleading to suggest that the sulphate 
content could be established simply by correlation with the $\mathrm{pH}$. Dr Loveland implies that in pyrite oxidation, sulphate is formed from initial sulphite. In fact, the original initial material is a sulphide.

No mention is made of the amount of water necessary to kcep the material moist. As this clearly affects the $\mathrm{pH}$ eventually measured, the relative proportions of soil and water should be specified. With reference to point $(d)$, further clarification is required on the amount of distilled or de-ionized water to be used, and how often the sample is to be stirred. It is assumed that $\mathrm{pH}$ is measured using an electrometric $\mathrm{pH}$ meter, such as that specified in BS 1377. The Authors would emphasize that $\mathrm{pH}$ measurements should be made as soon as possible after recovery of a sample in order to obtain consistency of results in all situations.

It is accepted that where drainage allows a drop in the ground water level, aeration will result and in this type of soil the production of sulphates will occur. In many engineering situations, however, other considerations may mean extensive drainage is essential. Our comment was intended to imply that when drainage is placed through material in which sulphates can be generated, it should be so designed that the removal of sulphates through flushing is encouraged, and the kind of accretion which may lead to sulphate crystallization and heave is prevented. (Hawkins \& Pinches, 1987).

It is acknowledged that the addition of material to neutralize acidity is expensive and often impractical. However, for specific buildings where remedial action is required due to sulphate activity after construction, it may be necessary to undertake such expensive treatment to prevent further reaction. Such treatment proved successful in Canada (Penner, Eden \& Gillott, 19773). It is hoped the Paper will help avoid the occurrence of such problems in the future, and hence the necessity for remedial action.

\section{REFERENCES}

Bloomfield, C. \& Coulter, J. K. (1973). Genesis and management of acid sulphate soils. Advances in Agronomy 25, 265-326.

British Standards Institution (1975). Methods of test for soils for civil engineering purposes BS 1377. London: HMSO.

Hawkins, A. B. \& Pinches, G. M. (1987) Cause and significance of heave at Llandough Hospital, Cardiff-a case history of ground floor heave due to gypsum growth. Q.J. Engr. Geol. 20, 41-57.

Penner, E., Eden, W. J. \& Gillott, J. E. (1973). Floor heave due to biochemical weathering of shale. Proc. 8th Int. Conf. Soil Mech. Fdn Engng., Moscow 2, $151-158$. 